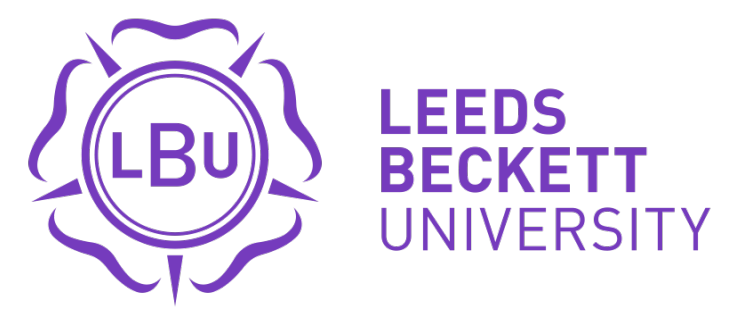

Citation:

Kamuhuza, W and Wu, J and Lodorfos, G and McClelland, Z and Rodgers, H (2021) The tripartite partnership between female entrepreneurs, banks and governments in female entrepreneurshipdevelopment: A case study of Zambia. International Journal of Organizational Analysis. ISSN 1934-8835 DOI: https://doi.org/10.1108/IJOA-08-2020-2387

Link to Leeds Beckett Repository record:

https://eprints.leedsbeckett.ac.uk/id/eprint/7378/

Document Version:

Article (Accepted Version)

Creative Commons: Attribution-Noncommercial 4.0

The aim of the Leeds Beckett Repository is to provide open access to our research, as required by funder policies and permitted by publishers and copyright law.

The Leeds Beckett repository holds a wide range of publications, each of which has been checked for copyright and the relevant embargo period has been applied by the Research Services team.

We operate on a standard take-down policy. If you are the author or publisher of an output and you would like it removed from the repository, please contact us and we will investigate on a case-by-case basis.

Each thesis in the repository has been cleared where necessary by the author for third party copyright. If you would like a thesis to be removed from the repository or believe there is an issue with copyright, please contact us on openaccess@leedsbeckett.ac.uk and we will investigate on a case-by-case basis. 


\title{
The tripartite partnership between female entrepreneurs, banks and governments in female entrepreneurship-development: A case study of Zambia
}

\author{
Womba Kamuhuza $^{\text {a }}$, Junjie Wu ${ }^{\text {b1 }}$, George Lodorfos ${ }^{\mathrm{c}}$, Zoe McClelland ${ }^{\mathrm{d}}$, Helen Rodgers ${ }^{\mathrm{e}}$ \\ ${ }^{a}$ Meanwood Finance Corporation Limited, Zambia \\ b,c,d,e Leeds Business School, Leeds Beckett University, Leeds, UK
}

\begin{abstract}
Purpose - This paper provides insights on the void between the needs and demands of bank finance from female entrepreneurs and the supply as well as the approaches of banks for that finance. In addition, it creates a conceptual framework recognising a tripartite and dynamic partnership among female entrepreneurs, banks and governments as essential to female entrepreneurship-development, based on Zambia as the context

Design/methodology/approach - Concepts and theories are explained to construct a conceptual framework using the lens of multi-polar network theory and stakeholder engagement theory. In-depth discussions are facilitated through a bilateral partnership between each party and tripartite partnerships among female entrepreneurs, banks and governments.
\end{abstract}

Findings - The framework presents how female entrepreneurs, banks and governments are interconnected in the network as mutually benefiting stakeholders and shows their collective contribution to female entrepreneurship-development within certain contexts. The findings suggest that the sustainable development of female entrepreneurship depends on a dynamic tripartite partnership among female entrepreneurs, banks and governments.

\footnotetext{
${ }^{1}$ Corresponding author: Dr Junjie Wu: J.Wu@leedsbeckett.ac.uk
} 
Research limitations/implications - The conceptual framework has important implications when setting up a nation's enterprise development strategies and policies promoting inclusivity and diversity among a nation's entrepreneurs. The contributions and the dynamic relationship of the three stakeholder groups should be acknowledged and considered in order to achieve the sustainable development of female entrepreneur enterprises. The framework can be generalised to other emerging economies with similar social, economic and cultural profiles to Zambia, particularly in sub-Saharan African countries with patriarchal norms.

Originality/value - This paper extends multi-polar (network) theory and Stakeholder Management engagement theory, previously explained in homogeneous firms, to more complex and dynamic partnerships among heterogeneous organisations, i.e. female entrepreneurs, banks and governments.

Keywords: female entrepreneurs; bank lending; government policy; female entrepreneurshipdevelopment; Zambia.

\section{Introduction}

The population of female entrepreneurs has been the fastest and largest growing segment in entrepreneurship in the last two decades, making significant contributions to the economy and society (Kelley et al., 2015). The growth of female entrepreneurs in sub-Saharan Africa ${ }^{2}$ is even more remarkable. According to 2018/2019 Women's Entrepreneurship Report of Global Entrepreneurship Monitor (GEM), the Total Entrepreneurial Activity (TEA) rate for women is $10.2 \%$ globally, but the highest rate $(21.8 \%)$ is recorded in sub-Saharan Africa compared to

\footnotetext{
${ }^{2}$ The region that our illustrated case - Zambia is located.
} 
other regions in the world (Elam et al., 2019). However, Elam et al., (2019) revealed that in terms of growth expectations, “...there is a substantial gender gap in that $18.7 \%$ of women entrepreneurs expect high growth compared to $29 \%$ of men entrepreneurs" (p. 9) and "the largest gender gap is in sub-Saharan Africa, where women reported high growth expectations half as often as men" (p.10). Arguably, supporting entrepreneurship in general and in particular female entrepreneurship in order to close the gap between male entrepreneurs and female entrepreneurs should become an important part of national and international socio-economic strategies. Governments in sub-Saharan Africa countries including Zambia take tackling gender inequity issues as one of their development strategies in "Vision 2030".

Gender inequalities disadvantage female entrepreneurs, to a greater extent, when they try to get access to finance compared to their male counterparts (Wellalage and Locke, 2017), which impedes their female entrepreneurship participation and prevents them from developing and growing existing and/or new ventures (Aterido et al., 2011). Many studies suggest that female entrepreneurs are discriminated by banks because they lack collateral from ownership of property and banks are unwilling to accept household assets as collateral, they have an incomplete credit record, and bank officials have little confidence on female entrepreneurs concerning their lower education attainment and training background (Isaga, 2019). In contrast, there are other scholars who have agreed that there is a lack of clear evidence of systematic gender discrimination in lending by financial institutions (Wang et al., 2020). However, many female entrepreneurs perceive or have witnessed this kind of discriminative treatments (Panda, 2018; Leitch et al., 2018; Isaga, 2019). Therefore, there are contradictory findings in the literature in relation to female entrepreneurs' access to finance, evidence of discrimination and the female entrepreneurs' own experiences.

There is consensus in the literature that gender inequalities cause females to experience great and disproportionate challenges in accessing opportunities and resources necessary to them or 
their businesses. However, reducing these inequalities and supporting female entrepreneurs in sub-Saharan Africa countries are extremely challenging because many of these countries and societies including Zambia are male-dominated, which historically and traditionally have patriarchal norms, attitudes, practices, and beliefs that exercise male dominance over female (Lambrecht, 2016). Therefore, the institutional, legislative and the cultural environment where the entrepreneurial activity is taking place contribute significantly to the gender inequalities that create difficulties for female entrepreneurs to access and obtain finance. Hence female entrepreneurs, financial institutions and, governments, as the essential legislation and policymaker, should work together to overcome the barriers, reduce the gender gap in entrepreneurship and create the necessary conditions for female entrepreneurs and their businesses.

Research on the government's role as a bridge between female entrepreneurs and financial institutions is fragmented and inconclusive. Several recent studies have explored the role of governments in promoting female entrepreneurs to help economic and social development. For example, in Pakistan, Yunis et al. (2019) found that female entrepreneurs struggle for sustainability, however positive changes to the fundamental constitution through formal and informal rules can enable entrepreneurship while institutional forces by governments' regulations and policies are important to drive the growth of social entrepreneurship. Ennis (2019) explored the government's focus in promoting female entrepreneurial activities in the Oman and Qatar, and identified female entrepreneurs as agents of state development who have a role to play in governance and politics. In a study which examines the gender gap in financial inclusion in Nigeria, Adegbite et al. (2020) suggested that the gender gap in financial inclusion can be narrowed through targeted strategies by the government. Another concept of entrepreneurial ecosystem introduced by Hechavarría and Ingram's (2019) also emphasised governments as one key stakeholder from a multi-stakeholder group who contributes to the 
sustainable development of a country's businesses. This paper investigated the effect of entrepreneurial ecosystems in 75 countries and asserted that in an entrepreneurial ecosystem, entrepreneurs' access to finance, government's supporting programs and policies, entrepreneurial education, legal and commercial infrastructure are essential components. Interestingly, one of their findings confirmed that female entrepreneurs "in patriarchal societies with formalised legal and commercial infrastructure might be less inclined to engage in venturing because they perceive unfair legal treatment and gender discrimination" (p. 442). These studies highlight that the sustainable development of female entrepreneurs depends on having networked stakeholder groups and enabling ecosystems, policies and strategies.

The argument that entrepreneurial firms and their entrepreneurs should establish relationships or networks with peers and other partners has been receiving increasing support from research studies. For example, Wright and Dana (2003) argue that along with the development of internationalisation, the world is moving from the unipolar paradigm focusing on firms to a multi-polar paradigm which values networking with other firms including competitors. To survive and succeed in the increasingly severe competitive world, entrepreneurial firms are required to cooperate and cultivate relationships with other firms and/or partners. Such connections switch from traditionally internalised direct ownership to mutually benefiting interdependence relationships with externals (Wright and Dana, 2003). These relationships are symbiotic (Dana et al., 2008) and can provide new niche markets for entrepreneurs (Wright and Dana, 2003). Vershinina et al. (2019) extend this argument to female entrepreneurs and argue that due to gender inequality, female entrepreneurs bear more liabilities in internal sources of capital such as knowledge and finance, compared to their male counterparts. As such, it is more important for female entrepreneurs to take advantage of their external stakeholders through engagements and collaborations in order to gain and develop sustained competitive capabilities. Vershinina et al. (2019) further point out that these gender-associated 
liabilities are caused by the fact that women contributions are not recognised and appreciated by the societies (especially in patriarchal societies) and result in a shortage of legitimacy for female entrepreneurs. Therefore, established stakeholder networks would help female entrepreneurs strengthening financial capital and gain stronger legitimate status, particularly in less developed countries where the legal system and property rights are weaker.

However, both Wright and Dana's multi-polar network model and Vershinina et al.'s stakeholder engagement theory were discussed (thus limited to) among homogeneous firms instead of heterogeneous organisations which have different functions/characteristics and therefore warrant further investigation which is what this paper aims to do. This paper sets up two objectives. First, we intend to provide a detailed illustration on the gap/void between the demand of bank finance from female entrepreneurs and supply approaches by banks for that finance via the 5C (Collateral, Capital, Capacity, Character, Condition) tools used by banks/financial institutions to evaluate female entrepreneurs' eligibility for finance. Second, using the lens of multi-polar network theory (see Wright and Dana, 2003) and stakeholder engagement discussion (see Vershinina et al., 2019), we propose a conceptual framework which recognises a tripartite and dynamic partnership between female entrepreneurs, banks and governments as a strategy to drive and foster female entrepreneurship-development, based on Zambia as the context. We argue that the conceptual framework is generalisable to other maledominated emerging countries, particularly to sub-Saharan African countries which share political and cultural contexts.

The rest of the paper is organised as follows. Section 2 highlights gender-specific challenges facing female entrepreneurs and explains gender inequality through the feminist lens. Section 3 demonstrates the $5 \mathrm{C}$ mismatched scenario observed between female entrepreneurs' demand for finance and banks' supply of finance and argues that there is a need to break the deadlock from an external party, while governments can act as the "icebreaker" using their power. 
Section 4 explains how governments facilitate finance supplying by banks to female entrepreneurs. Section 5 first demonstrates the bilateral partnership between female entrepreneurs, banks and governments respectively and then proposes a conceptual framework which narratively explains the tripartite partnership between the three stakeholders - female entrepreneurs, banks and governments. Section 6 concludes the paper and sheds lights on contributions, implications and limitations.

\section{Female entrepreneurs and gender inequality}

Gender is a central feature of feminism as it shapes female lives in many aspects (Marlow and McAdam, 2012), such as access to finance, income and education (Van Staveren, 2011). Even though female entrepreneurship plays an essential socio-economic role, it is limited due to the many challenges female entrepreneurs encounter. Many of these challenges are gender-specific and affect female entrepreneurs' ability to access opportunities and resources essential for entrepreneurial developments. All entrepreneurs face many challenges and risks (Langowitz and Minniti, 2007). Still, according to Mattis (2004), the risks are even more significant for female entrepreneurs, who also face gender-specific problems associated in a male-dominated field.

Gender inequality is perceived as stronger in traditional masculine (patriarchal) societies (for example, the majority of countries in Africa, such as Nigeria, Kenya, Uganda, Zimbabwe, Malawi, Tanzania, South Africa) because they have norms and beliefs that espouse a practice of male dominance over females (Lambrecht, 2016). This primarily attributes to social-cultural factors which regard and/or perceive females as less capable than their male counterparts, with a negative impact on female entrepreneurship (Hossain et al., 2009; Alvarez et al., 2011). In addition to the social and cultural factors there are legal factors that have a direct impact on 
asset ownership by female entrepreneurs. This is due to gender differences in property and legal rights regarding statutory and customary laws (Lambrecht, 2016). This problem is particularly acute in Africa and Asia. For example, in Kenya, customary law excludes married, divorced, separated and widowed females from inheriting from their parents and spouses or owning property in their names (Ellis et al., 2007). The United Nations (2010) report that in Africa, forty-five countries out of the forty-eight reviewed exhibited gender inequality regarding inheritance rights; and in Asia, the number was twenty-five out of forty-two countries.

Family is also a key factor influencing female entrepreneurship. Society views family and household responsibility as a traditional role for females (Evans, 2014). This position is exemplified by the United Nations Economic Commission for Europe (2012), which notes that “"the gendered division of labour continues to reflect traditional gender roles perceiving women as caregivers and men as breadwinners" (UNECE, 2012, p.39).

Liberal and social feminism explain the issues of female entrepreneurship from a different perspective related to this study (Calas et al., 2009; Kariv, 2013). Liberal feminism claims that female entrepreneurs are competent entrepreneurs, capable of producing comparable or equitable entrepreneurship output as their male counterparts (Calas et al., 2009), however, they are unable to maximise or reach their full potential due to discrimination or structural barriers by governments, banks and society. On the other hand, social feminism highlights the unique needs, experiences, competences and values of women (Kariv, 2013, p.49) and recognises that females possess key unique attributes that enhance entrepreneurship activities (McAdam, 2012). Social feminists also argue that female entrepreneurs are disadvantaged compared to their male counterparts due to society's allocation of roles and responsibilities, as well as structural barriers in institutions that support female entrepreneurship (e.g. family structure, social and cultural practices, education system, the broader ecosystem) (Harding, 1987, Marlow and McAdam, 2012). 


\section{Female entrepreneurs' demand for and supply finance by banks: a mismatched scenario}

Female entrepreneurs find that access to finance, which is essential to female entrepreneurship, is one of the most significant challenges they encounter during their entrepreneurial journey (Marlow and Patton, 2005; Ramadani et al., 2013). Female entrepreneurs are affected by "both the demand for and supply of credit on the part of the banking institution', (Bardasi et al., 2011, p.430). The difficulties facing female entrepreneurs in bank borrowing are attributed to genderspecific challenges and the criteria of bank loan applications that put female applicants in an inferior or disadvantaged position to male counterparts. Previous studies consistently suggest that female entrepreneurs receive a lower percentage and smaller amount loans, pay higher interest rates and provide additional collateral security (e.g., North et al., 2010; Beck et al., 2013). Recent studies provide evidence of the financial pressure that female entrepreneurs have been facing. For example, after systematically reviewing and ranking the constraints facing female entrepreneurs in 90 developing countries from 35 studies, Panda (2018) ranked financial constraints (difficulty in raising capital) as the top of the identified seven constraints to be addressed. In a survey of 400 female entrepreneurs in Tanzania, Isaga (2019) found access to finance as the most important inhibiting factor affecting their business growth. Other studies (e.g. Leitch et al., 2018; Wang et al., 2020) also confirmed the disadvantages of female entrepreneurs in seeking and obtaining external funding. Given the findings from these studies, it is difficult for female entrepreneurs to meet the development needs of their businesses and compete equally with their male counterparts.

With respect to whether female entrepreneurs receive obvious discrimination in bank lending, empirical evidence is contradictory. Some scholars (e.g. Becker-Blease and Sohl 2007; Marlow 
and Swail 2014) confirm that this is the case but others suggest that banks do not consciously use different evaluation tools which are purposely designed to discriminate against women, charge higher interest rates, decline applications, and/or require higher levels of collateral (e.g., Muravyev et al., 2009). A comprehensive study from Muravyev et al., (2009) based on data from more than 5,500 firms in 34 countries covering developing and developed suggested that market development play a vital role as less discrimination is associated with more developed financial markets, lower loan rejection rates and less collateral (Prasad, 2009).

These contradicting findings might be attributed to various factors, including the context and the scope of the studies. However, there is consensus, based on which we argue that the difficulties of female entrepreneurs in obtaining bank finance are largely caused on a mismatch between the demand of bank finance from female entrepreneurs and the supply, including the available products for that finance. The mismatch is highlighted in the financing models or tools used by banks to evaluate finance eligibility, generally referred to as the $5 \mathrm{Cs}$ (Collateral, Capital, Capacity, Character, Condition) (Coleman and Robb, 2009). In this section, we illustrate the mismatch through issues such as what female entrepreneurs need, how their applications for finance are evaluated, and what banks are prepared to offer.

The first C - Collateral refers to assets such as land or buildings that are used to secure bank finance and lack of/or insufficient collateral is one of the main reasons for loan rejection by financers (Erogbogbo et al., 2013). Therefore, collateral is the most important determinants of banks' supply of finance (Bruns and Fletcher, 2008) and the vital element in the 5Cs. Calice et al.'s (2012) investigation on bank financing of SMEs in Zambia, Kenya, Uganda and Tanzania concluded that access to finance was highly collateralised. However, previous research also suggests that females typically lack collateral in the form of land or property to pledge as security for bank finance (North et al., 2010). In Sub-Saharan Africa, about $75 \%$ of the land is 
administered under customary law (Joireman, 2008) ${ }^{3}$. Customary law tends to have inbuilt biases against females, and as such females encounter indirect legal barriers in the acquisition of land and property (Lambrecht, 2016).

Such weak property rights are directly connected to females' inability to control resources such as land and this limits their eligibility for finance as they fail to provide collateralised assets to financers, which puts them at a disadvantage to access finance (Klapper and Parker, 2011). The allocation of resources normally reflects society's gendered responsibilities and roles for males and females. It also highlights that the differences in access to collateral between male and female entrepreneurs are unlikely to be narrowed within the foreseeable future considering that changes in the legal framework and customary norms that govern the relationship between males and female access to resources require the evolution of the institutional, social and cultural environment (Demirguc-Kunt et al., 2013).

The second C stands for Capital which refers to the equity invested by the entrepreneur (owner) into the business. As capital (equity) reflects the business' financing pattern or strategy - a key driver of business performance and growth, banks consider equity invested into the business by the entrepreneur as an important criterion in accessing finance (Bruns and Fletcher, 2008).

However, the literature indicates that female entrepreneurs have a different financing pattern and strategy from their male counterparts. For example, female entrepreneurs are more likely to start and grow their businesses using their resources and access funds from friends and family than seeking formal external financing (Carter et al., 2007). Female entrepreneurs tend to invest limited amounts of equity into their businesses (Fairlie and Robb, 2009) because of

\footnotetext{
${ }^{3}$ For example, although the Zambian Constitution does not discriminate against females, in practice, Zambia has a dual land system which recognises both statutory and customary law (Gender Status Report 2012-14). In this system, $6 \%$ of land is administered by the state or government, while the remaining $96 \%$ is administered by chiefs (Gender Status Report 2012-14).
} 
their assumed risk-averse nature, which influences the capital structure by female-owned companies (Watson et al., 2014). The perceptions of female entrepreneurs and their subsequent behaviours towards financing affect their business growth and long-term performance (Treichel and Scott, 2006).

The third C, Capacity refers to the payback ability of the business or entrepreneur to bank service used (e.g. interest to the bank loans). Capacity is a pivotal determinant for banks to supply finance to businesses (Coleman and Robb, 2009). Banks measure capacity through business performance and growth, specifically through the increase in sales and profit and employment (Bruns and Fletcher, 2008). Employment provides access to entrepreneurship resources such as finance, where the social and human capitals held by employed females are more likely to encourage their engagement in female entrepreneurship (Allen et al., 2008). In this way, employment can act as an enabler towards the business incubation stage of female entrepreneurship.

However, females are disadvantaged in the labour market. For example, the Zambian labour market was male-dominated for several decades until the last three decades when the number of female employees began to increase (Gender Status Report, 2012-2014). In the Zambian labour market, females normally have low paying jobs, low education and are restrained by organisational glass ceilings; moreover, they usually have little savings and assets/collateral to enter and/or engage in female entrepreneurship by way of initial capital and security for bank finance (Ellis et al., 2007).

In addition, banks face another challenge in the credit evaluation of many female-owned businesses, because they are small in size, young in age (most are start-up) and limited in investment, which makes it difficult for lenders to seek recourse of owners' assets (Calice et 
al., 2012). Many of these businesses also lack a plausible track record to ascertain repayment history and profitability (Deakins et al., 2010).

The fourth $\mathrm{C}$ stands for Character which refers both to the character of the business in terms of its age and size, and the character of the entrepreneur (owner) in terms of his/her education, skills and experience. Banks assess business character through its age and size (usually measured by sales and profits, and the numbers of employees (Fairlie and Robb, 2009). Banks are normally not keen to provide funding for start-ups, early-stage and smaller businesses because of the high risk involved such as lack of track record, information, collateral, and unbuilt profitability (Fabowale et al., 1995). As such smaller and younger businesses are more likely to face high financing costs, e.g. higher administrative fees and interest rates than older and larger businesses. Within these parameters, female-owned businesses tend to be smaller and younger (Aterido et al., 2011). Research in thirty-four developed and developing countries conducted by Muravyev et al. (2009) found that female-owned businesses were one and a half years younger than their male counterparts.

The level of education influences both one's ability to enter and engage in entrepreneurship and generate resources, for instance, education, skills and work experience enhance the character of the entrepreneur which were considered important in the bank loan evaluation process (Deakins et al., 2010). However, females in developing countries are more likely to exhibit lower education levels than those in developed countries (Erogbogbo et al., 2013). Females' lack of/or limited education, experience and skills may act as a barrier to obtain finance, as it affects females' ability to assess the financial information required for obtaining finance. Research also suggests that female entrepreneurs encounter difficulties when dealing with complex financial products and services, which further limit female ability in providing appropriate bank loan application documentation (Richardson et al., 2004). Moreover, female entrepreneurs are found having less managerial experience than males because they occupy a 
disadvantaged position in the labour market (Mattis, 2004), which leads to financiers viewing their businesses "as being riskier and prone to failure"' (Fabowale et al., 1995, p.59) and hinders building a reputable track record to support their access to finance (Deakins et al., 2010).

Finally, the fifth $\mathrm{C}$ stands for Condition, which refers to the industry/sector that the businesses operate in and the financial position (Bruns and Fletcher, 2008). Banks prefer providing finance to the potentially profitable industries/sectors with higher levels of investment in tangible assets such as machines and buildings. However, female entrepreneurs' businesses tend to concentrate in traditional sectors such as service and retail because these sectors usually have lower entry barriers, require less financing and general business experience (Klapper and Parker, 2011; Demirguc-Kunt et al., 2013). The service and retail sectors are associated with low levels of investment on tangible assets such as machines and buildings, which makes them less attractive to banks (Wu et al., 2008). For example, the United Nations (2010) Report on the World's Women suggested that the service sector employs $70 \%$ of females worldwide. Studies also indicate that female-owned enterprises in the service and retail sector are at the lower end of the value chain with low margins, having limited growth and low survival rates (Fairlie and Robb, 2009). These factors make female entrepreneurs less attractive to banks (Deakins et al., 2010).

From reviewing the literature relating to the $5 \mathrm{Cs}$ from the perspectives of female entrepreneurs demanding finance and banks supplying the required finance, it is certain that there is a mismatch between the assumptions in the $5 \mathrm{Cs}$ model and the reality of female entrepreneurship. Carter et al. (2007) argue that banks are using the 5Cs in a stereotyped manner something that prevents female entrepreneurs from scoring high and thus gaining access to finance. Therefore, we argue that there is a need to break the deadlock externally. At the same time, governments 
(the third stakeholder) can act as the "icebreaker" applying their power to instigate change and their interest to support entrepreneurial activities leading to economic growth.

\section{Governments' role in facilitating finance supplying by banks to female entrepreneurs}

In the last section, we demonstrated the mismatch between what banks require from female entrepreneurs to secure financing and what female entrepreneurs could realistically offer in order to obtain funding for their enterprises. We, therefore, argue there is a need for an external stakeholder to build a bridge in order to narrow down the gap and enable or even facilitate bank lending to female entrepreneurs. In this section, we demonstrate why the government could act as the bridge-builder playing a supporting role without interfering into the business operations of either the banks or the female entrepreneur businesses.

At institutional and legitimate level, the government can support female entrepreneurship through policy formulation and implementation such as regulatory reforms and enactment of laws, business and trade facilities and policies that promote and support female entrepreneurship (Minniti, 2008; Lee et al., 2011). The government can influence female entrepreneurship through its political will to implement policies and strategies that address specific challenges and needs of female entrepreneurs, for example, through gender equality laws that allow females to have equal access to opportunities and resources such as finance (Shaw et al., 2009). This process can be enhanced by using gender ratios (Demirguc-Kunt et al., 2013), to balance the proportion of males and females accessing finance and property/assets and to provide evidence for targeted policies/solutions.

The government can also play a facilitative role by partnering with banks in jointly providing SME financing through financial reforms and supporting schemes such as partial credit guarantee funds (PCF) (Beck et al., 2006; Amine et al., 2009). For example, in the UK, the 
Department for Business Enterprise and Regulatory Reform under the Enterprise Finance Guarantee guaranteed $75 \%$ of loans for business owners without security for a conventional loan (NatWest, 2011). Banks favour these type of schemes as they can reduce banks' lending risk (Beck et al., 2006). In addition, the government can use other options, such as mutual credit guarantee schemes, which can remedy information asymmetries and transaction costs (Minniti, 2008).

The government can also take a step further by creating "an enabling environment that supports financial inclusivity for women"' (Erogbogbo et al., 2013, p.3), and by removing institutional and policy barriers; for instance, encouraging banks via incentives to support female entrepreneurs including tax relief, quotas and reduction in statutory bank reserves (Calice et al., 2012).

In the context of Zambia, the government prioritised reforms in the financial market to facilitate access to finance by individuals and businesses. As of 2015, there were nineteen commercial banks operating in Zambia, of which thirteen banks provide finance to SMEs (Mphuka et al., 2014). The Zambian government also reserves $30 \%$ of loan facilities for females through the Citizens Economic Empowerment Commission (CEEC) (Gender Status Report, 2012-2014). Moreover, in order to regulate, supervise and ensure an effective and efficient financial market, in 2004 the government initiated a vital policy - the implementation of Financial Sector Development Programme (FSDP) through the Central Bank (Bank of Zambia), which aimed to enhance female financial inclusivity. The FSDP includes three key themes that signalled the government's drive towards SME support, particularly female entrepreneurs. That is (1) enhancing Medium to Small Enterprises access to finance, (2) gender-sensitive strategies to enhance access to finance for female entrepreneurs and (3) developing financial literacy. All these factors signal government confidence in the vital role of female entrepreneurship and the need to tackle gender inequity issues towards progressive social and economic development. 


\section{Tripartite partnership: The Conceptual Framework}

Up to this point, we have highlighted gender inequality and bank discrimination against female entrepreneurs and demonstrated the mismatch between female entrepreneur funding needs and the criteria used by banks to evaluate their finance application. In addition, we also have demonstrated the role that a government could play bridging the gap between female entrepreneur demands/need and banks supply. From the discussion, we can see that female entrepreneurs have multiple gender-associated disadvantages (Vershinina et al., 2019) which hinder them from sourcing enough money, or even securing a loan, in particular from banks, to enable their businesses to survive and grow, thus hardly achieving the full potential and/or potential business value (Wright and Dana, 2003). In addition, considering the mismatched 5Cs with regards to female entrepreneurs and weak partnership ties between female entrepreneurs and banks the need for expanded networks including a broad range of stakeholders are needed. The group of stakeholders (i.e. governments in the context of this paper) should be formed in a way that provides the capability and capacity to solve, or at least mitigate the barriers to entrepreneurship development, and create an enabling ecosystem. It is evident that the proposed network should contain the elements proposed by Wright and Dana (2003) in their multi-polar network theory (e.g. forming collaborative partners, no direct ownership or control involvement, and having mutual benefits) but also involve heterogeneous organisations (i.e. firms, banks and governments) to complement each other.

In this section, we propose a conceptual framework (illustrated in Figure 1) which suggests a tripartite partnership between female entrepreneurs, banks and governments as a dynamic system to drive and foster female entrepreneurship-development within a business environment and/or context. In doing so, we first establish the role of a female entrepreneur in female 
entrepreneurship-development then we discuss the bilateral partnerships between female entrepreneurs, banks and governments, respectively. Finally, we conclude the dynamic tripartite partnership.

\section{Female entrepreneurship-development}

Even though there is not a consistent definition of development, there is consensus that development is intended to produce positive change or outcome for individuals and society (McGillivray, 2008) via a number of economic and social variables such as the production of goods and services, employment creation, innovation and competition (Acs et al., 2008; Bartholomew, 2015), education, poverty reduction; and acceptable living standards (Naude, 2013; Bartholomew, 2015). These outcomes are consistent with the returns from entrepreneurial activities and reinforce the argument that entrepreneurship facilitates development (Stokes and Harris, 2012; Si et al., 2015). To maximise the benefits of female entrepreneurs, there is a need for development plans/strategies/vision statements at the national level. For example, Zambia, as part of its medium to long term development plan, has developed the "Vision 2030", which is to make the country middle income, to reduce national poverty to below $20 \%$, to reduce inequalities, to provide better education, to improve sanitation and water supply, to increase food production, to improve and increase productivity in all sectors, to improve access to resources by all, and to improve health care.

Gender equality and access to resources by all are key measures and inputs contributing to development. Therefore, they are often included in strategies and programmes as key measures for monitoring and evaluation (Cornwall and Riva, 2015). Considering that female entrepreneurs are critical players in contributing to social-economic developments (Brush and Cooper, 2012), their empowerment and support as agents of change (Calas et al., 2009; 
Rindova et al., 2009) can maximise their potential impact. These benefits translate into long term economic growth (GEM 2017). Such an output reaffirms females as essential agents of economic development (Saparito et al., 2013), as suggested by Allen et al. (2008, p.6) that "ignoring the proven potential of women entrepreneurial activity means that countries put themselves at a disadvantage and thwart their opportunity to increase economic growth". Female entrepreneurs are also important social players in terms of poverty alleviation (Siringi, 2011; Scott et al., 2012), particularly as they tend to reinvest more of their income in their children's health, nutrition and education and the larger community than their male counterparts (Allen et al., 2008; Kelley et al., 2015).

Female entrepreneurs can provide additional economic and political benefits to entrepreneurship and society through the process and actions that female entrepreneurs use to drive their entrepreneurship strategy/agenda and entrepreneurial passion (Al-Dajani and Marlow, 2013, Kamuhuza, 2017, Cardon et al., 2009, 2013). For example, in Zambia, female entrepreneurs have adopted an economic emancipatory entrepreneurial model to drive their entrepreneurship through seeking autonomy (taking charge), authoring (pushing the agenda) and making declaration/s (voice) (Rindova et al., 2009). Through these processes and actions, the female entrepreneurs have started to change the entrepreneurship landscape, which was male-dominated. Female entrepreneurs have started gaining recognition as competent entrepreneurs who are able to deliver development target through their entrepreneurship output, a position which has resulted in the government pursuing gender equality policies.

Critical to leveraging and sustaining the benefits of the female entrepreneurship-development relationship is the partnership between key stakeholders such as the female entrepreneurs, the government and the banks. Partnerships are important instruments for driving and achieving agendas/strategies (IFC, 2013), particularly in sustainable development (World Economic Forum, 2018). This position is acknowledged by the Zambian government, through its 
emphasis in identifying key players and resources to drive, achieve and sustain 'Vision 2030' and is evidenced by the efforts made thus far, to collaborate with key stakeholders in the private sector (female entrepreneurs and banks) to enhance the relationship between female entrepreneurship and development.

Partnership 'involves co-creation, shared risks and responsibilities, interdependency, and organisational transformation. A true relationship is about identifying shared value and leveraging the combined strengths of each partner to achieve a level of impact that could not be accomplished independently' (KPMG, 2017). For the Zambian government, partnerships are critical (one of the seven pillars of Vision 2030) in achieving development by working with the private sector through Private-Public Partnerships (PPIs). The importance of partnership as a driving force, in achieving and sustaining development is also acknowledged by the United Nations (2010) by noting it as one of the tenets of the Global Sustainable Development Goals.

The partnership between female entrepreneurs and the government

Governments and female entrepreneurs are, by default, mutual partners who rely on each other to deliver personal and national development agendas. In this partnership, the government has the power to set up gender equality laws and supporting policies in order to help female entrepreneurs in accessing resources and opportunities equal to their male counterparts; in turn, female entrepreneurs will deliver significant socio-economic impact.

Taking Zambia as a case example, to achieve the government's development agenda, female entrepreneurship is identified as one of the development agents as it provides positive change or benefits to the population, the communities the society (Rindova et al., 2009) and the economy. The Zambian government has started taking forward this agenda through the National Gender Policy (NGP), adopted in 2000, which aims to attain gender equity and 
empowerment of females in all socio-economic and political areas. In addition, in order to accelerate the pace of female empowerment and to enhance females' social, cultural, economic and political development, the Zambian government, in December 2015, passed the Gender Equity and Equality Act (GEEA) (National Assembly of Zambia, 2016). Similarly, to increase female participation in all areas of social, political and economic development, in November 2015, the government passed the Gender Protocol 50-50. These initiatives demonstrate that the Zambian government has realised that female entrepreneurship requires interventions to meet its full potential and is undertaking actions to reverse female subordinate position to males when it comes to access to resources and opportunities.

In order to monitor and evaluate progress made against gender equality targets and inform policies, strategies and laws the government has the power and should integrate gender indicators (for instance, gender-disaggregated data) into information systems. This will make stakeholders aware of the progress made against gender equality targets and inform policies, strategies and laws. Moreover, the government, in partnership with female entrepreneurs, can develop entrepreneurial training, which can improve female entrepreneur competences (Fairlie and Robb, 2009) and resilience. Governments can also enhance female entrepreneurship by integrating entrepreneurship education in the curriculum (Kelley et al., 2011).

The partnering efforts between female entrepreneurs and governments can be measured through many indicators, for example, net increase of female owned businesses registered, percentage of female entrepreneurs who report increase in income in the last financial/trading year, newly created products and services for female entrepreneurs (e.g. dedicated credit, insurance, pension projects), percentage of female entrepreneurs who claim increased decisionmaking power in the household and/or firm, numbers of female entrepreneurs who have received business training with an increase in skills or obtained a higher education certificate, 
and percentage of female entrepreneurs who claim improved confidence and feeling of socially being recognised.

\section{The partnership between female entrepreneurs and banks}

Female entrepreneurs and their enterprises are an important market for banks in terms of income generation. Although female entrepreneurship and female economic empowerment can be facilitated and enhanced through access to finance, banks are often very reluctant to provide finance to SMEs in general and in particular female entrepreneurs (see the discussion about the mismatch of the 5Cs earlier). As a result, the market of bank lending to SMEs/female entrepreneurs in Africa remains undeveloped and far from saturation, compared to other emerging economies. For example, a study conducted by Demirguc-Kunt and Klapper (2012) using Enterprise Surveys data of 130,000 SMEs in 127 countries concluded that the banks' share of SME financing was only $8 \%$ in Africa and $11 \%$ in other emerging economies. Moreover, studies note that the SME sector in Sub-Saharan Africa is the most financially constrained among the developing region (Calice et al., 2012).

Specifically, the reasons for female entrepreneurs' limited access to bank financing include the fact that female entrepreneurs usually own younger ventures with less entrepreneurial experience; they have limited knowledge of banks' products and services, their businesses are small and informal with lack of ownership of property or land as collateral, and inadequate business and accounting records to prove borrowing capacity. These are key criteria in lending decision-making, as such, lending to female entrepreneurs is treated as high risks as per bankers' perceptions (McAdam 2012).

However, previous studies also present mixed results. Scholars argue that the different characteristics of female entrepreneurs to their male counterparts lead the peculiarity of their 
financial needs. If banks carefully consider and customise appropriate products and services, female entrepreneurs would be treated comparably to their male entrepreneurs (or even better than) with benefits for both entrepreneurs and banks. This is supported from studies suggesting that female entrepreneurs have a higher propensity for saving both as business owners and personal customers; thus, their businesses are potentially stable, growing and profitable (Stiglitz and Weiss 1983). In addition, Robb and Watson, (2012) argue that female entrepreneurs are very reliable in repaying bank debts experienced by many banks.

Moreover, female entrepreneurs are loyal customers: once they connect with a bank, they tend to explore other financial products and services (not limited to bank loans) from the same bank and tend to maintain long-term relationships (Beck et al. 2014). Female entrepreneurs also have a greater propensity for risk aversion, which positions them more conservative towards bank loan applications, particularly in the periods of financial uncertainty (e.g. financial crisis). This feature would be beneficial for banks regarding minimising bad debts (Cowling et al., 2020). The specificity of female entrepreneurs provides banks with opportunities to tailor their products and services to meet the needs of the special group of customers, e.g. relaxing collateral and documentarian requests, saving bundling, loyalty bonuses, rewarding insurance, and differential marketing campaigns are some of the approaches to develop and maintain good and long-term bank-female entrepreneurs relationship.

Furthermore, the current low level of SME/female entrepreneurs in access bank financing in Sub-Saharan Africa would arguably prove the opportunities and capacity for increasing bank financing to female entrepreneurs. This would boost female entrepreneurship activity and its noted benefits, increase banks' confidence in lending female entrepreneurs and generate returns on their investment. Some initiatives promoted by international organisations help build a bridge between female entrepreneurs and banks/financial institutions towards developing a harmonic relationship; for instance, the 'Strengthening Access to Finance for Women-owned 
SMEs' from the G-20 Global Partnership for Financial Inclusion (Global Banking Alliance for Women, 2016). These projects are partnering with local and international banks to promote female entrepreneurs in access to finance, training, education both in developed and developing countries (Global Banking Alliance for Female, 2016).

\section{The partnership between the government and banks}

Both governments and banks need to work together, ensuring economic growth and financial stability within different business environments. Currently, the bank lending market to female entrepreneurs is underdeveloped, and the financial products are not designed to meet the needs of female entrepreneurs, and the lending decision is made based on criteria that do not represent the current entrepreneurial landscape. Arguably, with interventions from the governments' support programmes, there is potential for banks to develop products suitable for female entrepreneurs and to take the unique characteristics of female entrepreneurs into consideration when making a lending decision. This would boost new venture creation and growth and enable banks to demonstrate financial inclusivity regardless of gender (GBA, 2017).

There is a debate about whether governments should interfere with the banking sector's operation; if yes, how (e.g. directly owning or intervening with projects, policies and regulations)? Scholars who support governments' interventions argue that the banking sector ${ }^{4}$ is different from other private sectors because it acts as a nation's money supplier and plays critical roles in a country's economy and social infrastructure. Therefore, governments' interventions can be justified by market failures and the country's development goals (see Gerschenkron, 1962; Stiglitz, 1994). Yeyati et al. (2004, p. 6-7) summarised four categories of governments' interventions in the banking sector including: “(i) maintaining the safety and

\footnotetext{
${ }^{4}$ It might argue that banking sector is a special private sector.
} 
soundness of the banking system; (ii) mitigating market failures due to the presence of costly and asymmetric information; (iii) financing socially valuable (but financially unprofitable) projects; and (iv) promoting financial development and giving access to competitive banking services to residents of isolated areas". The first and second type of government interventions provides protection in cases of market failure as evidenced by bail-outing some banks in the 2007-08 financial crisis. The third and fourth groups of interventions take a development view and emphasise the governments' supportive functions, for example, in providing special funding projects to the socially profitable but financially unattractive ventures (e.g. female owned enterprises), helping expand banking accessibility, and setting up banking regulations to support economic and social development.

Empirically, there is evidence to support the argument that government interventions have a positive impact on banking; consequently, benefit its clients. For example, Calderon and Schaeck (2016) examined the correlation between the governments' approaches and interventions (i.e. blanket guarantees, liquidity support, recapitalizations, and nationalizations) and banking sector competitions. They concluded that these approaches are positively correlated with increasing banks' market shares in deposit and loan amounts, in turn the increase of banks' competitive capabilities. Practically, governments in many countries work with the banking sector through effective projects, policies and regulations to support female entrepreneurs without interfering with the operation of the banks. In Zambia, banks have already started working with the government as a partner in the Female and Male Operated Enterprise (FAMOS) Tool initiative that aims to tailor finance for the requirement of female entrepreneurs. Similar programmes have gone a step further in co-financing with the government in order to ease the challenges female entrepreneurs are facing in gaining access to finance. These initiatives have the potential to improve access to opportunities and resources for female entrepreneurs and create a balance with male counterparts. This partnership is 
consistent with "Vision 2030", which calls for private-public partnerships (PPIs) between the government and private sector players (for example, banks) to drive the entrepreneurshipdevelopment relationship.

A tripartite partnership among female entrepreneurs, banks and the government

From the discussions above, we have established a conceptual framework (see Figure 1) that explains a tripartite partnership among female entrepreneurs, banks and the government in achieving development through female entrepreneurship.

Female entrepreneurs have the capacity and the capability to develop entrepreneurial activities with potential for socio-economic impact. Therefore, they are fighting to get societal recognition that their entrepreneurial activities should be valued and supported to the same extent as their male counterparts. Female entrepreneurs accept that their approach and their starting position are different to male entrepreneurs and this should be factored in the models used to evaluate applications for funding and the systems of entrepreneurial support offered to them.

Governments are key legislation players who provide necessary conditions for female entrepreneurs to thrive. Governments are also crucial in brokering the relationship between the demand side (i.e. female entrepreneurs) and the supply side (i.e. banks and other financial institutions).

Banks are key institutional players who can develop products appropriate for female entrepreneurs, through the funding application evaluation process they could shape and improve business plans to reduce risks and maximise potential returns and can work collaboratively with the government to provide incentives (i.e. grants, tax breaks, training, advisors) to foster female entrepreneurship. 
The conceptual framework illustrates the tripartite relationship between female entrepreneurs, banks and the government towards development through female entrepreneurship. It also demonstrates a mutually beneficial and dynamic relationship between the tripartite partners/stakeholders. For female entrepreneurs, increased access to finance will enhance their female entrepreneurship output and improve their credit record; for banks, increased supply of products and finance to female entrepreneurs will reinforce their income generation streams and improve their competitive position; for the government, the organic relationship of finance supply and demand will lead to socio-economic benefits such as employment creation, economic growth, innovation and poverty reduction, as well as longer-term economic and social development.

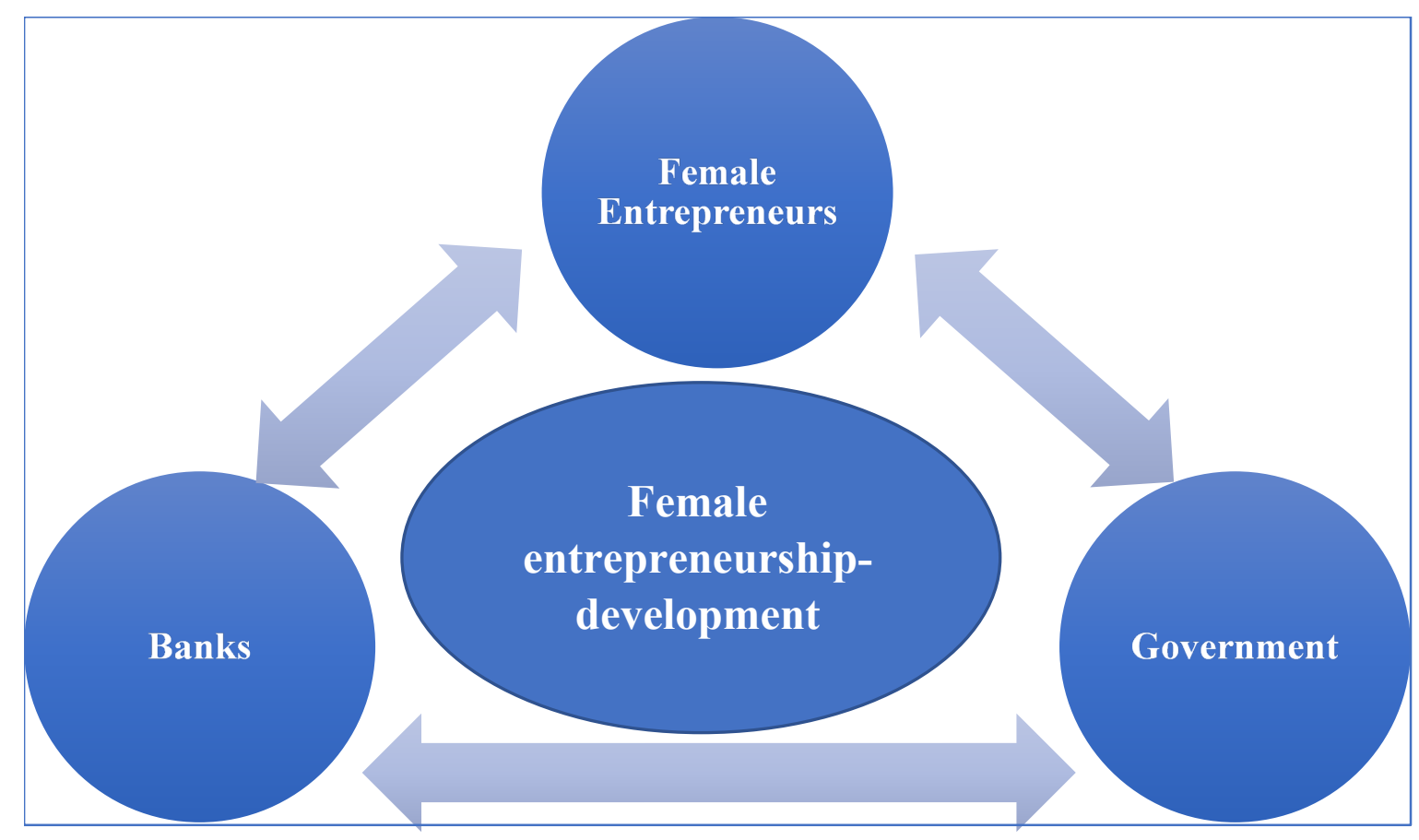

Figure 1: The tripartite partnership among female entrepreneurs, banks and the government

\section{Conclusion}


This paper advances a conceptual framework that demonstrates that a tripartite partnership between female entrepreneurs, banks, and the government has the potential to drive and foster female entrepreneurship, sequent development in a gender inequality country. The conceptual framework illustrates the tripartite relationship where female entrepreneurs demand finance, banks supply funding, and the government coordinates regulates the demand and supply of finance and provides the necessary infrastructure (the ecosystem) to foster female entrepreneurship. It also asserts that only when the tripartite partnership is dynamic, the development would be sustainable.

The contributions of this paper to the extant literature are fourfold. First, it initially demonstrates, via 5C tools, the mismatch between the demand for bank finance from female entrepreneurs and supply approaches by banks for that finance to justify governments' intervention and supporting role. Second, the current paper extends the multi-polar network theory (Wright and Dana, 2003) and Stakeholder Management discussion (Vershinina et al., (2019) among homogeneous firms to more complicated partnerships among heterogeneous organisations - female entrepreneurs, banks and governments. Moreover, the study not only reveals bilateral partnerships between female entrepreneurs and banks, female entrepreneurs and governments, and banks and governments, respectively; but also demonstrates the tripartite partnership among the three stakeholder groups, and how the relationship works and what involves in it. Third, the conceptual framework illustrates a dynamic tripartite partnership between the three key stakeholders in the female entrepreneurship-development relationship, rather than the bilateral partnerships suggested in other articles. This tripartite partnership suggests that female entrepreneurship and development can be optimised only when the three groups of stakeholders complement each other. Fourth, this paper has discussed the conceptual framework in African countries, taking Zambia as the context. In this way, we have provided rich insights into the context of this conceptual framework and the rationale that could make it 
applicable to other African or other emerging economies. This conceptual framework can be useful in explaining the challenges and prosperities of female entrepreneurs in obtaining opportunities and resources in other developing countries.

The conceptual framework has important implications when setting a nation's development strategies, vision and policies. The contributions and dynamic relationship of the three partner groups should be acknowledged and considered in order to achieve sustainable development. Finally, one obvious yet justifiable limitation of this research is the intentional and unashamed focus on Zambia, as the illustrative case. The Zambian case illustration promises a bright future for female entrepreneurship, in terms of access to finance with all the beneficial economic and social outcomes that ensue. We also acknowledge the need for more comparative cases and cross-sectoral studies, in emerging economies, to add nuanced understandings to the tripartite partnership. Furthermore, there is also a requirement to scrutinise, in more localised detail, the gender-disaggregated data in the short, medium and longer-term, to appraise improvements and checks and balances necessary for an ongoing and sustainable relationship within the tripartite female entrepreneurship-development circuit. We, therefore, call for more researchers to critique and enrich the conceptual framework in order to extend and be able to explain it in a broader context.

\section{References}

Acs, Z.J., Desai, S. and Klapper, L.F. (2008), “What does 'entrepreneurship' data really show?” Small Business Economics, Vol. 31 No. 3, pp. 265-281.

Adegbite, O. O., and Machethe, C. L. (2020), "Bridging the financial inclusion gender gap in smallholder agriculture in Nigeria: An untapped potential for sustainable development", World Development, Vol. 127, 104755. https://doi.org/10.1016/j.worlddev.2019.104755

Al-Dajani, H. and Marlow, S. (2013), "Empowerment and entrepreneurship: a theoretical framework", International Journal of Entrepreneurial Behaviour and Research, Vo. 19 No. 5, pp.503-524. 
Allen, I.E., Elam, A., Langowitz, N. and Dean, M. (2008), Global Entrepreneurship Monitor 2007 report on women and entrepreneurship. The Centre for Women's Leadership, Babson. Available from: $<$ www.gemconsortum.org $>$ [Accessed 10 ${ }^{\text {th }}$ June, 2013].

Alvarez, C., Urbano, D., Coduras, A. and Ruiz-Navarro, J. (2011), "Environmental conditions and entrepreneurial activity: a regional comparison in Spain", Journal of Small Business and Enterprise Development, Vol. 18 No. 1, pp. 120-140.

Amine, L.S. and Staub, K.M. (2009), "Women entrepreneurs in sub-Saharan Africa: an institutional theory analysis from a social marketing point of view", Entrepreneurship and Regional Development, Vol. 21 No. 2, pp. 183-211.

Aterido, R., Beck, T. and Iacovone, L. (2011), "Gender and finance in Sub-Saharan Africa: are women disadvantaged?” World Bank, Policy Research Working Paper 5571.

Bardasi, E., Sabarwal, S. and Terrell, K. (2011), "How do female entrepreneurs perform? Evidence from three developing regions", Small Business Economics, Vol. 37, No. 4, pp. 417441.

Baron, R.A. (2008), "The role of affect in the entrepreneurial process", Academy of Management Review, Vol. 33 No. 2, pp. 328-340.

Beck, T. and Demirguc-Kunt, A. (2006), "Small and medium enterprises: access to finance as a growth constraint”, Journal of Banking and Finance, Vol. 30 No.11, pp. 2931-2943.

Beck, T., Demirguc-Kunt, A. and Peria, M.S.M. (2009), "Bank financing for SMEs: evidence across countries and bank-ownership types", European Banking Centre Discussion, No.200971.

Beck, T., Behr, P. and Madestam, A. (2014), "Sex and credit: Is there a gender bias in lending, Working Paper: 29. Cass Business School, City University, London.

doi: https://doi.org/10.2139/ssrn.1923649.

Becker-Bhase, J., and Sohl, J. (2007), "Do women-owned businesses have equal access to angel capital?” Journal of Business Venturing, Vol. 22 No. 4, pp. 503-521.

Bruns, V. and Fletcher, M. (2008), "Banks' risk assessment of Swedish SMEs", Venture Capital, Vol. 10 No. 2, pp.171-194.

Brush, C.G. and Cooper, S.Y. (2012), "Female entrepreneurship and economic development: an international perspective", Entrepreneurship and Regional Development, Vol. 24 No.1/2, pp. 1-6.

Calas, M.B., Smircich, L. and Bourne, K.A. (2009), "Extending the boundaries: refining 'entrepreneurship as a social change' through feminist perspectives", Academy of Management Review, Vol. 34 No. 3, pp. 552-569.

Calderon, C. and Schaeck, K. (2016), "The effects of government interventions in the financial sector on banking competition and the evolution of zombie banks", Journal of Financial and Quantitative analysis, Vol. 51 No. 4, pp. 1391-1436. 
Calice, P., Chando, V.M. and Sekioua, S. (2012), "Bank financing to small and medium enterprises in East Africa: findings of a survey in Kenya, Tanzania, Uganda and Zambia", African Development Bank Group, No.146. Working Paper Series.

Cardon, M.S., Vincent, J., Singh, J. and Drnovsek, M. (2009), "The nature and experience of entrepreneurship passion", Academy of Management Review, Vol. 34 No. 3, pp. 511-532.

Cardon, M.S., Gregoire, D.A., Stevens, C.E. and Patel, P.C. (2013), "Measuring entrepreneurial passion: Conceptual foundations and scale validation", Journal of Business Venturing, Vol. 28 No. 3, pp.373-396.

Cardon, M.S. and Kirk, C.P. (2015), "Entrepreneurship passion as mediator of the self-efficacy to persistence relationship", Entrepreneurship Theory and Practice, Vol. 39 No. 5, pp.10271050 .

Carter, S., Shaw, E., Lam, W. and Wilson, F. (2007), "Gender, entrepreneurship, and bank lending: Criteria and processes used by bank loan officers in assessing applications", Entrepreneurship Theory and Practice, Vol. 31(3), pp. 427-444.

Central Statistics Office (2016), "Living conditions monitoring survey report", Lusaka. Available

from: $<$ www.zamstats.gov.zm/phocadownload.Living_Conditions/2015\%20Living\%20Condi tions\%20Monitoring\%20Survey\%20Report.pdf $>$ [Accessed $29^{\text {th }}$ February, 2018]

Coleman, S. and Robb, A. (2009), "A comparison of new firm financing by gender: evidence from the Kauffman firm survey data”, Small Business Economics, Vol. 33 No. 4, pp. 397-411.

Cornwall, A. and Rivas A. (2015), 'From 'gender equality and women's empowerment' to global justice: reclaiming a transformative agenda for gender and development", Third World Quarterly, Vol. 36 No. 2, pp. 396-415.

Cowling, M., Marlow, S. and Liu, W. (2020), "Gender and bank lending after the global financial crisis: are women entrepreneurs safer bets?", Small Bussiness Economics, Vol. 55, pp. 853-880.

Dana, L. P. (2001), "The education and training of entrepreneurs in Asia", Education and Training, Vol. 43 No. 8, pp. $405-416$.

Deakins, D., Whittam, G. and Wyper, J. (2010), "SMEs' access to bank finance in Scotland; an analysis of bank manager decision making", Venture Capital, Vol. 12 No. 3, pp. 193-209.

Demirguc-Kunt, A., and Klapper, L. (2012), "Financial inclusion in Africa". The World Bank, Policy Research Working Paper, 6088.

Demirguc-Kunt, A., Klapper, L. and Singer, D. (2013), "Financial inclusion and legal discrimination against women: evidence from developing countries", The Work Bank, Policy Research Working Paper, 6416. 
Elam, A. B., Brush, C. G., and Greene, P. G. (2019), "Global Entrepreneurship Monitor 2018/2019: Women's Entrepreneurship Report”. Global Entrepreneurship Research Association; Babson College; Smith College; Korean Entrepreneurship Foundation.

Ellis, A., Cutura, J., Dione, N, Gillson, I, Manuel, C. and Thongori, J. (2007), "Gender and economic growth in Kenya: unleashing the power of women", World Bank, Washington DC.

Ennis, C. A. (2019), "The gendered complexities of promoting female entrepreneurship in the Gulf”, New Political Economy, Vol. 24 No. 3, pp. 365-384.

Evans, A. (2014), “'Women can do what men can do': The causes and consequences of growing flexibility in gender division of labour in Kitwe, Zambia", Journal of Southern African Studies, Vol. 40 No. 5, pp. 981-998.

Erogbogbo, V., Eghobamien, E. and Pimentel, E. (2013), Gender responsive investment handbook: addressing the barriers to financial access for women's enterprises. Commonwealth Secretariat, London.

Fabowale, L., Orser, B. and Riding, A. (1995), "Gender, structural factors and credit terms between Canadian small businesses and financial institutions", Entrepreneurship Theory and Practice, Vol. 19 No. 4, pp. 41-65.

Fairlie, R.W. and Robb, A.M. (2009), "Gender differences in business performance: evidence from the characteristics of business owner's survey", Small Business Economics, Vol. 33 No. 4, pp. 375-395.

Gender Status Report - Zambia 2012-2014: Available from: https://www.zamstats.gov.zm, [Accessed 30th December, 2016]

Gerschenkron, A. (1962), "Economic Backwardness in Historical Perspective”, Harvard University Press.

Global Banking Alliance for Women (2016), "The paradox of gender-neutral banking", Available from: <www.gbaforwomen.com> [Accessed 30th December, 2016]

Global Banking Alliance for Women (2017), "Untapped Potential", Available from: $<$ www.gbaforwomen.com> [Accessed 2nd March, 2017]

Global Entrepreneurship Monitor (2017), Global Report. Babson. Available from: $<$ www.gemconsortum.org $>$ [Accessed $2^{\text {nd }}$ March, 2018].

Harding, S. (1987), “Introduction: Is there a feminist method?" In: Harding, H. ed. Feminism and methodology, Bloomington, Indiana University Press, pp. 1-14.

Hechavarría, D. M., and Ingram, A. E. (2019), "Entrepreneurial ecosystem conditions and gendered national-level entrepreneurial activity: a 14-year panel study of GEM", Small Business Economics, Vol. 53 No. 2, pp.431-458. 
Hossain, A., Naser, K., Zaman, A. and Nuseibeh, R. (2009), "Factors influencing women business development in the developing countries: Evidence from Bangladesh", International Journal of Organizational Analysis, Vol. 17 No. 3, pp. 202-224.

International Finance Corporation (2013), “Access to finance: Sub-Saharan Africa”, Available from:

$<$ www.ifc.org/wps/wcm.commect/e8eae004149f9f48008a39e7815671/For+Print+E+FY+hig hlights.pdf?MOD=AJPERES $>$ [Accessed 26 February 2018]

Isaga, N. (2019), "Start-up motives and challenges facing female entrepreneurs in Tanzania". International Journal of Gender and Entrepreneurship. Vol. 11 No. 2, pp. 102-119.

Joireman, S.F. (2008), "The mystery of capital formation in Sub-Saharan Africa: Women, property rights, and customary law”, World Development, Vol. 36 No. 7, pp. 1233-1246.

Kamuhuza, W. (2017), "SME Entrepreneurship - Access to finance for female entrepreneurs in Zambia", PhD Thesis, Leeds Beckett University, England.

Kariv, D. (2013), Female entrepreneurship and the new venture creation: An international overview. London: Routledge.

Kelley, D., Bosma, N. and Amoros, J.E. (2011), Global Entrepreneurship Monitor, 2010 Global Report. Babson. Available from: <www.gemconsortum.org $>$ [Accessed $10^{\text {th }}$ June, 2013].

Kelley, D., Brush, C., Green, P., Herrington, M. and Penny A. (2015), "Global Entrepreneurship Monitor (GEM) Women's Report 2015”, Available from:

$<$ www.gemconsortum.org $>$ [Accessed 14th July, 2016].

Klapper, L and Parker, S.C. (2011), "Gender and the business environment for new firm creation”, World Bank Research Observer, Vol. 26 No. 2, pp. 237-257.

KPMG (2017), "Unlocking the Power of Partnership". Available from: $<$ www.home.kpmg.com $>$ [Accessed $9^{\text {th }}$ January, 2018].

Lambrecht, I.B. (2016), “'As a husband I will love, lead, and provide': Gendered access to land in Ghana", World Development, Vol. 88, pp. 188-200.

Langowitz, N. and Minniti, M. (2007), "The entrepreneurial propensity of women. Entrepreneurship", Theory and Practice, Vol. 31 No. 3, pp. 341-364.

Lee, J.H., Sohl, S.Y. and Ju, Y.H. (2011), "How effective is government support for Korean women entrepreneurs in small and medium enterprises", Journal of Small Business Management, Vol. 49 No. 4, pp. 599-616.

Leitch, C., Welter, F., and Henry, C. (2018), "Women entrepreneurs' financing revisited: taking stock and looking forward: New perspectives on women entrepreneurs and finance", Venture Capital, Vol. 20 No. 2, pp. 103-114. 
Loscocco, K. and Bird, S.R. (2012), "Gendered paths: why women lag behind men in small business success", Work and Occupation, Vol. 39 No. 2, pp. 183-219.

Marlow, S. and Patton, D. (2005), “All credit to men? Entrepreneurship, finance and gender", Entrepreneurship Theory and Practice, Vol. 29 No. 6, pp. 717-735.

Marlow, S. and McAdam, M. (2012), "Analysing the influence of gender upon high technology venturing within the context of business incubation", Entrepreneurship Theory and Practice, Vol. 36 No. 4, pp. 655-675.

Marlow, S. and McAdam, M. (2013), "Gender and entrepreneurship: Advancing debate and challenging myths; exploring the mystery of the under-performing female entrepreneur", International Journal of Entrepreneurial Behaviour and Research, Vol. 19 No. 1, pp.114-124.

Marlow, S., and Swail, J. (2014), “Gender, risk and finance: Why can't a woman be more like a man?” Entrepreneurship \& Regional Development, Vol. 26 No. 1-2, pp. 80-96.

Mattis, M. (2004), "Women entrepreneurs: out from under the glass ceiling", Women in Management Review, Vol. 19 No. 3, pp. 154-163.

McAdam, M. (2012). Female Entrepreneurship. London: Routledge.

McGillivray, M. (2008), “What is development?” In D. Kingsbury, J. McKay, J. Hunt, M. McGillivry and M. Clarke (eds) International Development: Issues and Challenges. London, Palgrave Macmillan, pp. 21-50.

Minniti, M. (2008), "The role of government policy on entrepreneurial activity: productive, unproductive, or destructive?" Entrepreneurship Theory and Practice, Vol. 32 No. 5, pp. 779-790.

Mphuka, C., Simumba, J., Maboshe, M. and Banda, B. (2014), "Supply-side opportunities and constraints of bank credit to MSMEs in Zambia: lessons and implication for policy", Investment Climate and Business Environment Research Fund. Available from: $<$ www.trustafrica.or/icbe $>$ [Accessed 20th December, 2015].

Muravyev, A., Talavera, O. and Schafer, D. (2009), "Entrepreneurs' gender and financial constraints: evidence from international data", Journal of Comparative Economics, Vol. 37 No. 2, pp. 270-287.

National Assembly of Zambia (2016), "Gender Equity and Equality Bill”, Available from:

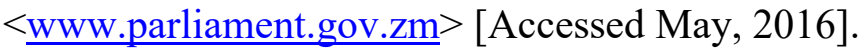

National Women's Business Council (2016), “10 million strong: The tipping point for women's entrepreneurship", Available from: < $\underline{w w w . n w b c . g o v}>$ [Accessed 2 March 2016].

NatWest Bank (2011), "Business Banking, tailored services for women in business”, London.

Naude, W. (2013), "Entrepreneurship and economic development, theory, evidence and practice". Discussion Paper, IZA DP No. 7507, July. Available from: < www.SSRN$\underline{\mathrm{id} 2314802 . p d f}>$ [accessed 10/2/16]. 
North, D., Baldock, R. and Ekanem, I. (2010), "Is there a debt finance gap relating to Scottish SMEs? A demand-side perspective", Venture Capital, Vol. 12 No. 3, pp.173-192.

Panda, S. (2018), "Constraints faced by women entrepreneurs in developing countries:

Review and ranking”. Gender in Management: An International Journal, Vol. 33 No. 4, pp. 315-331.

Prasad, R. M. (2009), "Loan Hurdles: Do banks discriminate against women entrepreneurs?" Academy of Management Perspectives, Vol. 23 No. 4, pp. 91-93.

Ramadani, V., Gërguri, S., Dana, L.P. and Tašaminova, T. (2013) "Women entrepreneurs in the Republic of Macedonia: waiting for directions", International Journal of Entrepreneurship and Small Business, Vol. 19 No. 1, pp. 95-121.

Richardson, P., Howarth, R. and Finnegan, G. (2004), "The challenges of growing small businesses: Insights from women entrepreneurs in Africa", SEED Working Paper No. 47. WEDGE-ILO.

Rindova, V., Barry, D. and Ketchen, D.J. (2009), "Entrepreneuring as emancipation”, Academy of Management Review, Vol. 34 No. 3, pp. 477-491.

Robb, A. M. and Watson, J. (2012), "Gender differences in firm performance: Evidence from new ventures in the United States”, Journal of Business Venturing, Vol. 27 No. 5, pp.544-558.

Saparito, P., Elam, A. and Brush, C. (2013), "Bank-firm relationship: do perceptions vary by gender", Entrepreneurship, Theory and Practice, Vol. 37 No. 4, pp. 837-858.

Scott, L., Dolan, C., Johnstone-Louis, M., Sugden, K. and Wu, M. (2012), "Enterprise and inequality: A study of Avon in South Africa", Entrepreneurship, Theory and Practice, Vol. 36 No. 3, pp. 543-568.

Seers, D. (1972), “What are we trying to measure?”, Journal of Development Studies, Vol. 8 No. 3, pp. 21-36.

Si, S., Yu, X., Wu, A., Chen, S., Chen, S. and Su, Y. (2015), "Entrepreneurship and poverty reduction: A case study of Yiwu, China", Asia Pacific Journal of Management, Vol. 32 No. 1, pp. 119-143.

Shaw, E., Marlow, S., Lam, W. and Carter, S. (2009), "Gender and entrepreneurial capital: implications for form performance", International Journal of Gender and Entrepreneurship, Vol. 1 No. 1, pp. 25-41.

Siringi, E.M. (2011), "Women's small and medium enterprises for poverty alleviation in SubSaharan Africa: lessons from Kenya", Management Research Review, Vol. 34 No. 2, pp. 186206.

Stiglitz, J. and Weiss, A. (1983), "Incentive effects of terminations: Applications to the credit and labor markets", The American Economic Review, Vol. 73 No. 5, pp. 912-927. 
Stiglitz, J. (1994), "The Role of the State in Financial Markets." Proceedings of the World Bank Annual Conference on Economic Development 1993. Washington, DC, United States: World Bank.

Stokes, P. and Harris, P. (2012), "Micro-moments, choice and responsibility in sustainable organizational change and transformation - The Janus dialectic", Journal of Organizational Change Management, Vol. 25 No. 4, pp. 595-611.

Treichel, M.Z. and Scott, J.A. (2006), "Women-owned businesses and access to bank credit: Evidence from three surveys since 1987”, Venture Capital, Vol. 8 No. 1, pp. 51-67.

United Nations (2010), “The World's Women in 2010 - Trends and Statistics”, United Nations, New York, Department of Economic and Social Affairs. Available from: $<$ www.unstats.un.org $>$ [Accessed 20 June, 2015].

United Nations Economic Commission for Europe (2012), "Promoting gender equality and women's economic empowerment on the road to sustainable development: good practices from the UNECE region”, United Nations, New York.

Van Staveren, I. (2011), "From gender as exogenous to gender as endogenous in the new economics". In: Arestis, P. and Sawyer, M. eds. New economics as mainstream economics. Basingstoke: Palgrave Macmillan.

Vershinina, N., Rodgers, P., Tarba, S., Khan, Z. and Stokes, P. (2019), “Gaining legitimacy through proactive stakeholder management: The Experiences of high-tech women entrepreneurs in Russia", Journal of Business Research, https://doi.org/10.1016/j.jbusres.2018.12.063

Wang, X., Cai, L., Zhu, X., and Deng, S. (2020), “Female entrepreneurs' gender roles, social capital and willingness to choose external financing", Asian Business \& Management, https://doi.org/10.1057/s41291-020-00131-1

Watson, J., Gatewood, E.J., Lewis, K. (2014), "A framework for assessing entrepreneurial outcomes: an international perspective", International Journal of Gender and Entrepreneurship, Vol. 6 No.1 pp. 2 - 14.

World Bank (2008), Finance for all? Policies and Pitfalls in expanding access. The World Bank, Washington, DC.

World Bank (2018), "The World Bank in Zambia - Country Overview", Available from

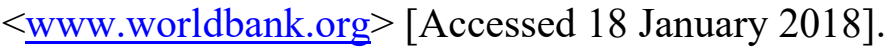

World Economic Forum (2018), "Why Partnership is the Business Trend to Watch", Available from $<$ www.weforum.org $>$ [Accessed $9^{\text {th }}$ January, 2018].

Wright, R. W. and Dana, L.P. (2003), "Changing paradigms of international entrepreneurship strategy", Journal of International Entrepreneurship, Vol.1 No. 1, pp. 135-152,

Wu, J., Song, J. and Zeng, C. (2008), “An empirical evidence of small business financing in China”, Management Research News, Vol. 31 No. 12, pp. 959-975. 
